2016

\title{
Grassroots Numeracy
}

H. L. Vacher

University of South Florida, vacher@usf.edu

Follow this and additional works at: https://digitalcommons.usf.edu/numeracy

Part of the Scholarship of Teaching and Learning Commons

\section{Recommended Citation}

Vacher, H. L.. "Grassroots Numeracy." Numeracy 9, Iss. 2 (2016): Article 2. DOI: http://dx.doi.org/10.5038/ 1936-4660.9.2.2 


\title{
Grassroots Numeracy
}

\begin{abstract}
The readers and authors of papers in Numeracy compose a multidisciplinary grassroots interest group that is defining and illustrating the meaning, content, and scope of quantitative literacy (QL) and how it intersects with educational goals and practice. The 161 Numeracy papers that have been produced by this QL community were downloaded 42,085 times in a total of 178 countries, including all 34 OECD countries, during 2015 and the first quarter of 2016. A scatterplot of normalized downloads per month vs. normalized total downloads for the eight years of Numeracys life allows identification of the 24 "most popular" of the 161 papers. These papers, which range over a wide landscape of subjects, were produced by a total of 41 authors, only nine of whom are mathematicians. The data clearly show that the QL community is not just a bunch of mathematicians talking amongst themselves. Rather the community is a vibrant mix of mathematicians and users and friends of mathematics. The heterogeneity of this grassroots community, and Numeracys commitment to serve it, dictates our mode of publication and the nature of our peer review. The journal is assertively open access for readers and free of page charges and processing fees to authors. The peer-review process is designed to provide constructive feedback to promote effective communication of the diverse activities and interests of a community that brings with it a multitude of publication cultures and experiences.
\end{abstract}

\section{Keywords}

quantitative literacy, mathematics education, grassroots academics, open-access publishing

Creative Commons License

$$
\text { (c) (1) (8) }
$$

This work is licensed under a Creative Commons Attribution-Noncommercial 4.0 License

\section{Cover Page Footnote}

Len Vacher is a professor of geology in the School of Geosciences at the University of South Florida and a founding co-editor of this journal. 
In the journal Polity, Filner (2002) uses the term grassroots harvest in the title of an essay review of two books. ${ }^{1}$ In it, he says:

... both books articulate a vision of community in which local citizens are the motors of democratic renewal. In this "grassroots" approach, citizens meet, discuss, plan, organize, and implement a variety of programs and policies that benefit their neighborhoods, communities, and ultimately the nation as a whole. People working at the grassroots level produce something that cannot be found in formal political institutions, something that sustains democracy. This "grassroots harvest" is a distinctive feature of the institution of civic practices, and the future of democracy depends on maximizing the yield.

With this quotation lifted from a political science context as a guide, can we think of ourselves as a QL community advancing education in quantitative literacy? Can we "articulate a vision of community in which" mathematicians and users and friends of mathematics "are the motors" advancing education in quantitative literacy? Is it reasonable to think that "In a 'grassroots' approach," these scholars of QL would "meet, discuss, plan, organize and implement," and, to the point of Numeracy, study and publish on a variety of issues, ideas, activities, courses, programs, and policies "that benefit their" students, their departments, their institutions, "and ultimately" the workplace and society? If so, this journal aspires to be the outlet and dissemination vehicle for the scholarly products of that community - a grassroots harvest of sorts-aiming to sustain (or promote, depending on one's perspective) quantitative literacy.

Numeracy's service to the QL community determines our mode of publication. Not only are we open access to readers; we are also free of page charges and processing fees for the authors. All publication costs of Numeracy are borne by the USF Tampa Library as part of its mission to support open-access publishing. Our publishing platform, bepress (Berkeley Electronic Press), expresses it well: "We believe the future of scholarly publishing lies in the hands of libraries and scholars to provide open access and effective research dissemination." 2 For more, please see the editorial in this issue by Borchert and Boczar.

\section{The Grasslands}

Where is the community? Perhaps a glimpse is provided by asking "who is downloading papers in Numeracy? The world map of Figure 1 shows a sample in the 24 hours before this sentence was written.

\footnotetext{
${ }^{1}$ Paul S. Grogan and Tony Proscio. 2000.

Carmen Sirianni and Lewis Friedland. 2001.

${ }^{2}$ http://www.bepress.com/aboutbepress.html
} 


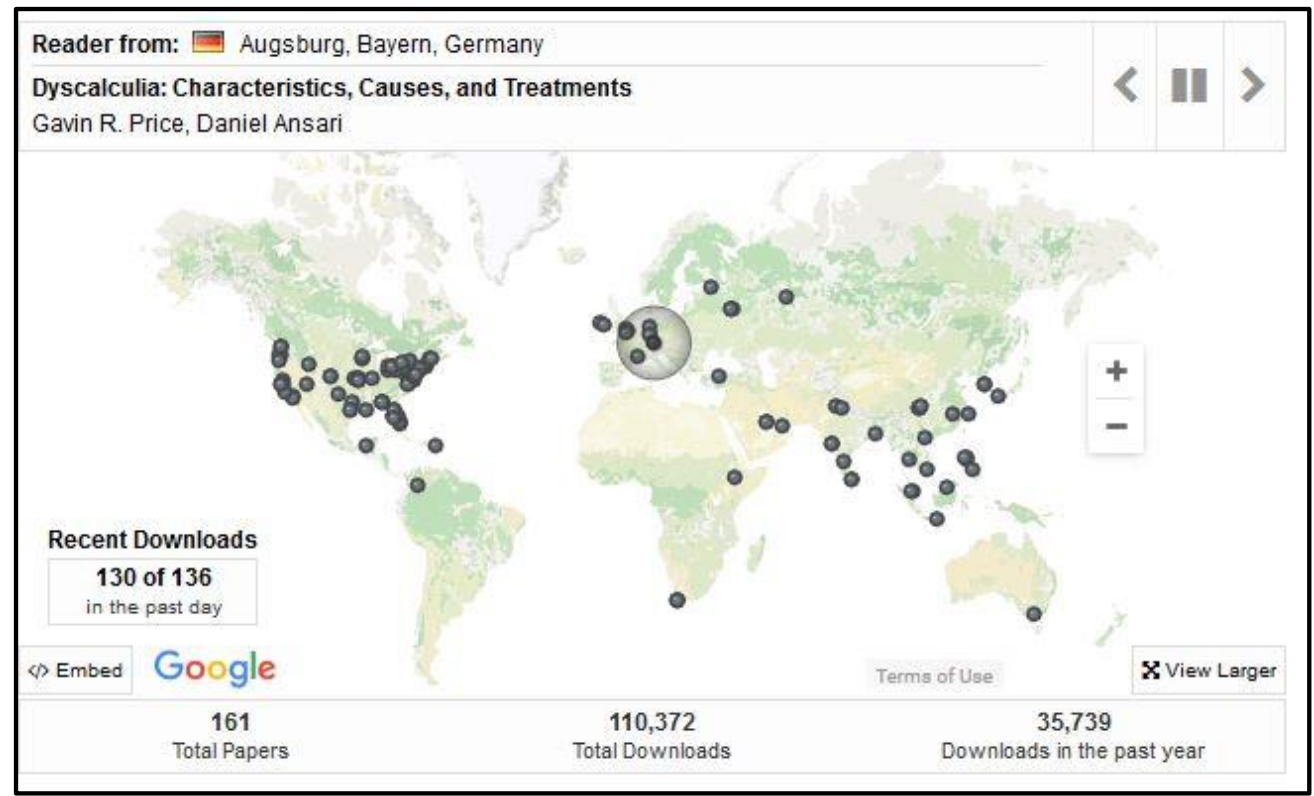

Figure 1. Snip from the map at the bottom of the home page of Numeracy at 9:00 am EDT, May 18, 2016, showing location of 130 of the 136 downloads of Numeracy papers in the preceding 24 hours. ${ }^{3}$

More information on the distribution of downloads is given in the table in the Appendix. In 2015 and the first quarter of 2016, there were 42,085 downloads from a total of 178 "countries" (including such entities as Bermuda and Puerto Rico that are not included in the 193 member states of the UN). About $50 \%$ of the downloads were in the U.S. The top 10 countries by downloads had about $75 \%$ of the downloads. The top 34 countries by downloads (down to Saudi Arabia, with 147) had $90 \%$ of the downloads. The top 100 countries (down to Tunisia and Kazakhstan, with 15 each) had $99 \%$ of the downloads.

All 34 member countries of the Organisation for Economic Co-operation and Development (OECD) downloaded papers (see appendix). About 29,000 (69\%) of the 42,000 total downloads were in OECD countries. Putting the ca. 21,000 downloads from the U.S. aside (from both numerator and denominator), about $62 \%$ of the non-U.S. downloads were from outside the OECD countries $(13,106 / 21,223)$.

\section{The Various Leaves}

Stretching the metaphor a bit, we can say that Numeracy harvested 161 leaves of grass (articles, perspectives, notes, book reviews, editorials and columns) in the

\footnotetext{
${ }^{3}$ The "Total Downloads" at the bottom of the map are about 24,500 too few. It appears that the count was restarted in mid-2012.
} 
17 issues since the first issue in January 2008. These papers were downloaded a total of about 129,600 times as of the end of March 2016. These downloads are shown in Figure 2 for each paper in a scatter plot of total downloads vs. issue number. The figure clearly shows that a paper's total

downloads is a function of age and, let's say,

"popularity." The latter variable spreads the dots out vertically for a given issue. For reference, the outlier dot is the ordered pair (11, 16,485) representing the review paper by Price and Ansari (2013) on dyscalculia. It was in the $11^{\text {th }}$ issue (vol 6 , iss 1) and has been downloaded 16,485 times.

Twenty-four dots are highlighted in the graph by a surrounding red box. These papers are selected as examples of Numeracy papers that drew exceptional interest either by number of

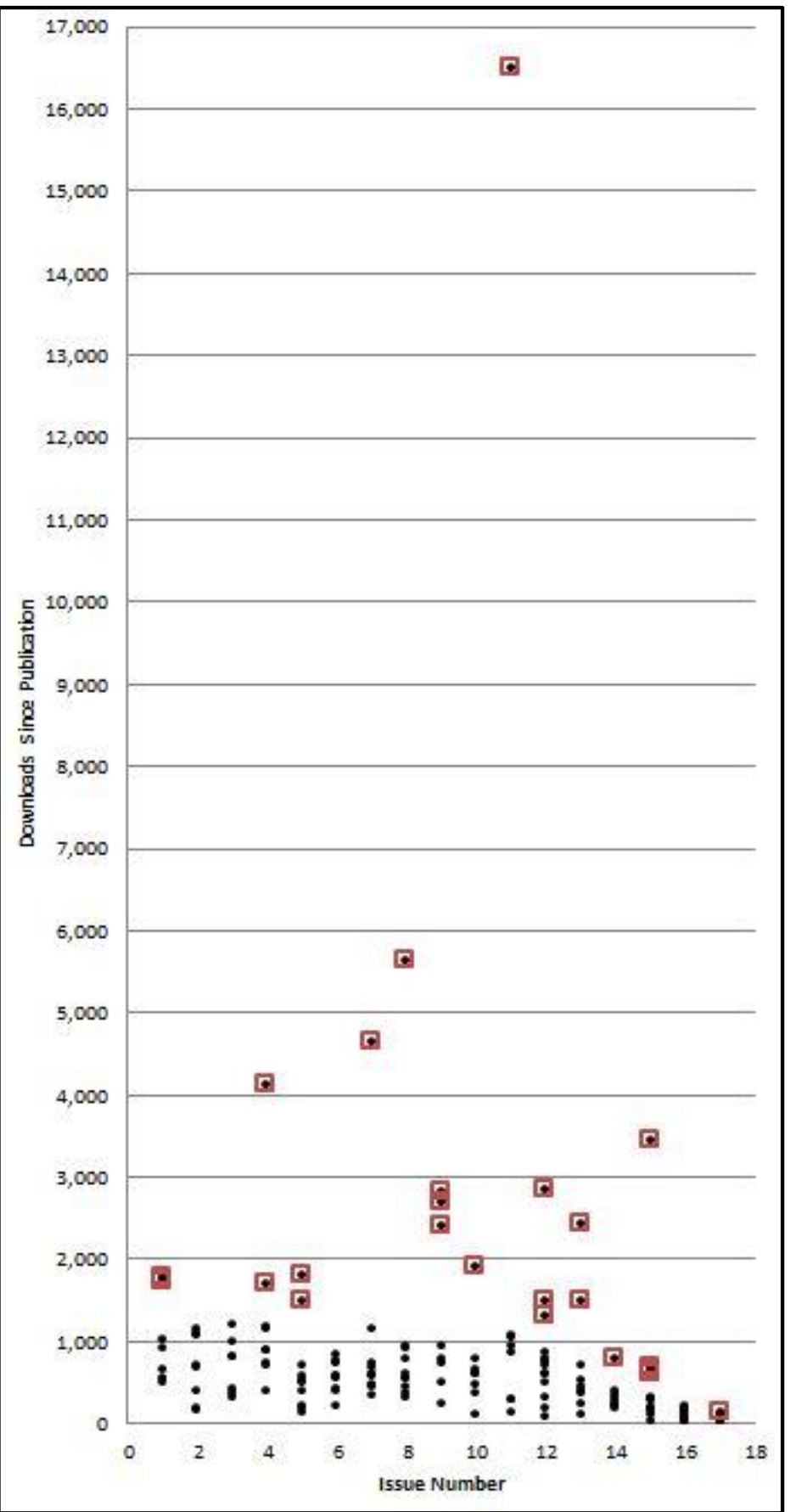

Figure 2. Downloads since publication vs. issue number. Red boxes indicate the most popular 24 papers (Fig. 3, Tables 1 and 2). 
downloads or by download rate or a combination of the two (see Fig. 3, particularly the explanation in the figure caption). They are listed individually in Table 1, in order from left to right, then down, as they occur in Figure 2. Thus the outlier point is the $13^{\text {th }}$ paper in the list, although it is clearly the one with the most downloads.

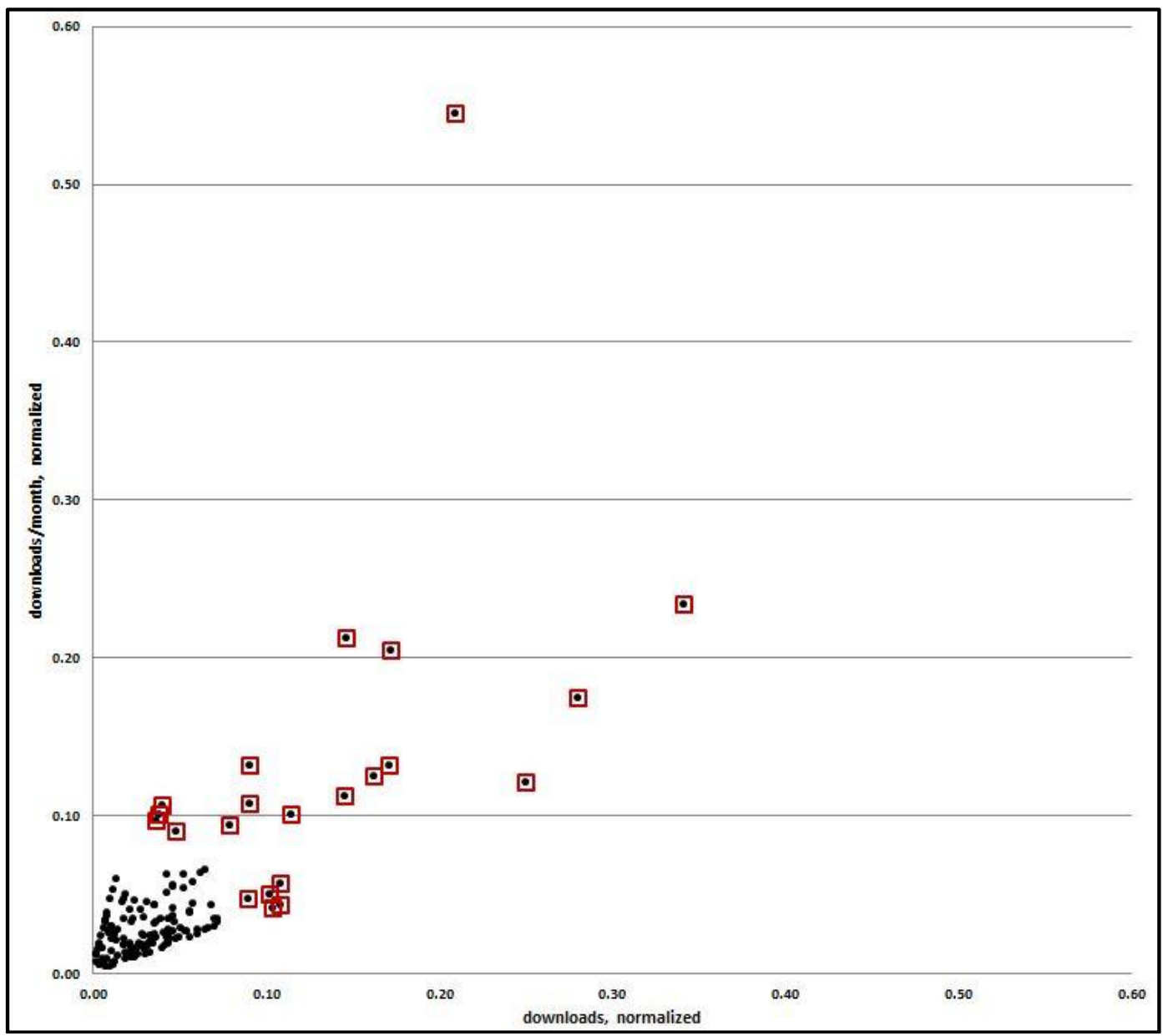

Figure 3. Normalized download rate (dwnlds/mo) vs. normalized downloads for the 160 papers.

The most downloaded paper (the Discalculia review) is off the chart and would plot at $(1.0,1.0)$ on this graph. In other words, it is the paper used to normalize (scale) the data. Its downloads and dwnlds/mo are 16,485 and 422.7, respectively. The downloads and dwnlods/mo of the second-most downloaded paper (Hassad 2011) are 5629 and 98.8, respectively. It, therefore, plots at $(8,5629)$ on Figure 2 and at $(0.34,0.23)$ here. Its distance from the origin in this graph is $\operatorname{SQRT}\left(0.34^{\wedge} 2+0.23^{\wedge} 2\right)=0.414$. Meanwhile the "highest" paper on this plot at $(0.21,0.54)$ is the relatively recent book review by Catalano (2015), which plots at $(15$, 3453 ) on Figure 2. Its distance from the origin is 0.584 . Dots that lie at high angles on this plot tend to be recent papers; dots that lie at low angles tend to be older. The criterion for boxing the dots is that the distance from the origin to the dot is 0.1 or more. 
Browsing the titles in Table 1 gives a good feel for the range of Numeracy and hence the interests of the QL community. The mathematics ranges from the most basic numeracy (e.g., Papers 12 and 13)] to college algebra (6) and calculus (7 and 11). Assessment is an ongoing topic (5, 8 and 23). There is self-reflection (2, 19, and 24). Allied literacies include financial literacy $(9,14,15,16,17$, and 18), statistics and statistical literacy $(1,8,20$, and 22)]. Fields of application include economics and social issues [( 3 and 6), health and biology [( 7 10, and 22), and writing and argument (5). Disposition is making an appearance (11 and 21), and so is cognitive load (23).

Table 1

The 24 Most Popular Papers: Order and Coordinates on Figure 2, Titles and Types

\begin{tabular}{|c|c|c|c|}
\hline Paper & (Issue, Dwnlds) & Title & Type \\
\hline 1 & $(1,1789)$ & Birds-Dead and Deadly: Why numeracy needs to address social construction & 3,7 \\
\hline 2 & $(1,1724)$ & Evolution of numeracy and the National Numeracy Network & 3 \\
\hline 3 & $(4,4,130)$ & Measuring resource inequality: The Gini coefficient & 1,5 \\
\hline 4 & $(4,1692)$ & Review of Super Cruncher by Ian Ayers & 7 \\
\hline 5 & $(5,1797)$ & A rubric for assessing quantitative reasoning in written arguments & 2,5 \\
\hline 6 & $(5,1488)$ & College algebra in context: A project incorporating social issues & 1,5 \\
\hline 7 & $(7,4,633)$ & $\begin{array}{l}\text { Calculus, biology and medicine: A case study in quantitative literacy for } \\
\text { science students }\end{array}$ & 1,9 \\
\hline 8 & $(8,5,629)$ & $\begin{array}{l}\text { Constructivist and behaviorist approaches: Development and initial evaluation } \\
\text { of a teaching practice scale for introductory statistics at the college level }\end{array}$ & 2,7 \\
\hline 9 & $(9,2,824)$ & Numeracy, financial literacy, and financial decision-making & $3,5,8$ \\
\hline 10 & $(9,2,678)$ & $\begin{array}{l}\text { Incorporating quantitative reasoning in common core courses: Mathematics } \\
\text { for The Ghost Map }\end{array}$ & $1,5,7$ \\
\hline 11 & $(9,2,405)$ & $\begin{array}{l}\text { Motivation for achievement and attitudes toward mathematics instruction in a } \\
\text { required calculus course at the Norwegian University of Science and } \\
\text { Technology }\end{array}$ & $6,7,9$ \\
\hline 12 & $(10,1,901)$ & $\begin{array}{l}\text { Number sense: The Underpinning understanding for early quantitative } \\
\text { literacy }\end{array}$ & 1,4 \\
\hline 13 & $(11,16,485)$ & Dyscalculia: Characteristics, causes, and treatments & 3,4 \\
\hline 14 & $(12,2,846)$ & $\begin{array}{l}\text { Financial literacy and financial behavior among young adults: Evidence and } \\
\text { implications }\end{array}$ & $1,3,5,8$ \\
\hline 15 & $(12,1,499)$ & Financial literacy and credit card behaviors: A cross-sectional analysis by age & $1,3,5,8$ \\
\hline 16 & $(12,1,309)$ & Financial literacy and retirement planning in Australia & $3,5,8$ \\
\hline 17 & $(13,2,416)$ & $\begin{array}{l}\text { Review of Financial Intelligence for Entrepreneurs: What You Really Need to } \\
\text { Know about the Numbers by Karen Berman and Joe Knight, with John Case. }\end{array}$ & $1,5,8$ \\
\hline 18 & $(13,1,497)$ & $\begin{array}{l}\text { Financial literacy and the success of small businesses: An observation from a } \\
\text { small business development center }\end{array}$ & 3,8 \\
\hline 19 & $(14,796)$ & $\begin{array}{l}\text { Looking at the multiple meanings of numeracy, quantitative literacy, and } \\
\text { quantitative reasoning }\end{array}$ & 3 \\
\hline 20 & $(15,3,453)$ & $\begin{array}{l}\text { Review of Naked Statistics: Stripping the Dread from Data by Charles } \\
\text { Wheelan }\end{array}$ & $1,5,7$ \\
\hline 21 & $(15,674)$ & $\begin{array}{l}\text { Improving university students' perception of mathematics and mathematics } \\
\text { ability }\end{array}$ & 1,6 \\
\hline 22 & $(15,637)$ & $\begin{array}{l}\text { Cancer clusters in Delaware? How one newspaper turned official statistics } \\
\text { into news }\end{array}$ & 3,7 \\
\hline 23 & $(15,614)$ & $\begin{array}{l}\text { Effects of reducing the cognitive load of mathematics test items on student } \\
\text { performance }\end{array}$ & $1,2,6$ \\
\hline 24 & $(17,140)$ & $\begin{array}{l}\text { What's in a name? A critical review of definitions of quantitative literacy, } \\
\text { numeracy, and quantitative reasoning }\end{array}$ & 3 \\
\hline
\end{tabular}

Last column: (1) For and about teaching. (2) Assessment. (3) QL, about. (4) QL, numeracy. (5) QL, content.

(6) QL, disposition. (7) Statistics and statistical literacy. (8) Financial literacy. (9) STEM 
Returning to the quotation at the beginning of this editorial, who are the people working at the grassroots level? From the perspective of Numeracy, they are the authors of the papers that appear in the journal.

Table 2

The 24 Most Popular Papers: Number of Authors and the Authors' Disciplines

\begin{tabular}{|c|c|c|}
\hline 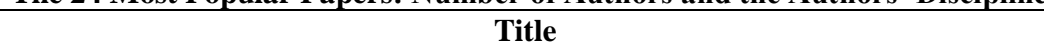 & Authors & Disciplines \\
\hline Birds-Dead and Deadly: Why numeracy needs to address social construction & 1 & soc \\
\hline Evolution of numeracy and the National Numeracy Network & 2 & math, math \\
\hline Measuring resource inequality: The Gini coefficient & 3 & $\begin{array}{l}\text { math, math, } \\
\text { math }\end{array}$ \\
\hline Review of Super Cruncher by Ian Ayers & 1 & math \\
\hline A rubric for assessing quantitative reasoning in written arguments & 3 & $\begin{array}{l}\text { econ, psych, } \\
\text { hist }\end{array}$ \\
\hline College algebra in context: A project incorporating social issues & 1 & math \\
\hline Calculus, biology and medicine: A case study in quantitative literacy for science students & 2 & educ, math \\
\hline $\begin{array}{l}\text { Constructivist and behaviorist approaches: Development and initial evaluation of a teaching } \\
\text { practice scale for introductory statistics at the college level }\end{array}$ & 1 & psych \\
\hline Numeracy, financial literacy, and financial decision-making & 1 & econ \\
\hline $\begin{array}{l}\text { Incorporating quantitative reasoning in common core courses: Mathematics for The Ghost } \\
\text { Map }\end{array}$ & 1 & biol \\
\hline $\begin{array}{l}\text { Motivation for achievement and attitudes toward mathematics instruction in a required } \\
\text { calculus course at the Norwegian University of Science and Technology }\end{array}$ & 4 & $\begin{array}{l}\text { psych, educ, } \\
\text { educ, stats }\end{array}$ \\
\hline Number sense: The Underpinning understanding for early quantitative literacy & 1 & math ed \\
\hline Dyscalculia: Characteristics, causes, and treatments & 2 & psych, psych \\
\hline Financial literacy and financial behavior among young adults: Evidence and implications & 1 & coll Bus \\
\hline Financial literacy and credit card behaviors: A cross-sectional analysis by age & 2 & econ, econ \\
\hline Financial literacy and retirement planning in Australia & 3 & bus, bus, bus \\
\hline $\begin{array}{l}\text { Review of Financial Intelligence for Entrepreneurs: What You Really Need to Know about } \\
\text { the Numbers by Karen Berman and Joe Knight, with John Case. }\end{array}$ & 1 & geol \\
\hline $\begin{array}{l}\text { Financial literacy and the success of small businesses: An observation from a small business } \\
\text { development center }\end{array}$ & 2 & educ, bus \\
\hline $\begin{array}{l}\text { Looking at the multiple meanings of numeracy, quantitative literacy, and quantitative } \\
\text { reasoning }\end{array}$ & 1 & geol \\
\hline Review of Naked Statistics: Stripping the Dread from Data by Charles Wheelan & 1 & math \\
\hline Improving university students' perception of mathematics and mathematics ability & 2 & math, educ \\
\hline Cancer clusters in Delaware? How one newspaper turned official statistics into news & 3 & soc, soc, soc \\
\hline Effects of reducing the cognitive load of mathematics test items on student performance & 3 & $\begin{array}{l}\text { ed psych, ed } \\
\text { psych, psych }\end{array}$ \\
\hline $\begin{array}{l}\text { What's in a name? A critical review of definitions of quantitative literacy, numeracy, and } \\
\text { quantitative reasoning }\end{array}$ & 3 & $\begin{array}{l}\text { math, cptr sci, } \\
\text { music }\end{array}$ \\
\hline
\end{tabular}

The 24 papers listed in Table 1 have a total of 41 different authors from a wide variety of fields (Table 2). Only nine of those authors in Table 2 are mathematicians. There are nearly as many from psychology (partly reflecting the psychometrics of educational measurement and assessment). The others come from various directions: economics, sociology, business, education, history, natural science, music, computer science, and statistics. The table clearly supports the statement at the beginning that, to the extent that we are a 
community, the QL community consists of mathematicians and users and friends of mathematicians. It is certainly not the case that we are a bunch of mathematicians talking amongst themselves. And it's the same for Numeracy: we are not a math journal — although mathematics is the sun of our solar system.

\section{Implications to Numeracy}

The statistics on author disciplines and global downloads show that the subject matter discussed in Numeracy transcends fields of study, and it crosses national boundaries. We know from eight years of experience - and the data support our perception-Numeracy serves a multidisciplinary community that brings with it a vast array of cultures regarding publishing practices, habits, and experience. Of particular interest, the number-one priority for many in our community is, and has been, in-the-trenches teaching while coping with prodigious teaching loads; increasingly, we are getting manuscripts from first-time authors, whom we welcome. These facts determine the nature of our peer-review process. Our purpose is to disseminate the work that is going on in the grassroots. Our peer review process is not so much a gate keeper as a gateway ${ }^{4}$ - meaning that our reviewers work hard to give constructive feedback to guide promising authors. We typically send the manuscript to three to five reviewers that reflect the range of readers who we think will be interested in the paper. Although we have outright rejected some papers after peer review, the most common "negative" result is "major revision required before acceptance," with a pathway, or at least a vision, to increase the likelihood of acceptance; hardly anyone gets better than "accepted with minor revisions." With three to five interested, dedicated reviewers, it is almost guaranteed that there will be some good suggestions for improvement, whether substantively or in terms of readability. Typically, manuscripts that don't get published fail because the authors do not follow through with the revisions - not because we don't want the author's contribution to the scholarship of QL. Think of the journal as a multidisciplinary community builder.

\section{References}

Bryk, A.S., and Uri Treisman. 2010. “Make Math a Gateway, Not a Gatekeeper. The Chronicle of Higher Education. http://www.completecollege.org/docs/Pre\%20Reading,\%20CCA\%20Remedi ation\%20Institute.pdf (downloaded May 20, 2016)

\footnotetext{
${ }^{4}$ Not an original turn of phrase; e.g., see Bryk and Treisman 2010
} 
Catalano, Michael T. 2015. "Review of Naked Statistics: Stripping the Dread from Data by Chares Wheelan." Numeracy 8 (1): Article 13.

http://dx.doi.org/10.5038/1936-4660.8.1.13

Filner, Matthew F. 2002. “Grassroots Harvest: Assessing the 'Post-Ideology' of

Pragmatic Communitarianism. Polity 35 (2): 311-323.

Grogan, Paul S., and Tony Proscio. 2000. Comeback Cities: A Blueprint for

Urban Neighborhood Revival. Boulder: Westview Press.

Hassad, Rossi A. 2011. "Constructivist and Behaviorist Approaches:

Development and Initial Evaluation of a Teaching Practice Scale for

Introductory Statistics at the College Level." Numeracy 4 (2): Article 7.

http://dx.doi.org/10.5038/1936-4660.4.2.7

Price, Gavin R., and Daniel Ansari. 2013. Dyscalculia: Characteristics, Causes, and Treatments. Numeracy 6 (1): Article 2.

http://dx.doi.org/10.5038/1936-4660.6.1.2

Sirianni, Carmen, and Friedland, Lewis. 2001. Civic Innovation in America: Community Empowerment, Public Policy, and the Movement for Civic Renewal. Berkeley: University of California Press.

\section{Appendix}

\begin{tabular}{|l|l|}
\hline \multicolumn{2}{|l|}{ Numeracy Downloads by Country, 2015 and First Quarter of 2016 (March 30, 2016) } \\
\hline Rank & Country (number of downloads) \\
\hline $1-10$ & $\begin{array}{l}\text { United States (20,852); Philippines (2,037); India (1,858); United Kingdom (1,516); Malaysia (1,056); } \\
\text { Australia (990); Indonesia (952); China (934); Canada (902); Germany (659); }\end{array}$ \\
\hline $11-20$ & $\begin{array}{l}\text { South Africa (641); France (475); Pakistan (354); Singapore (348); Nigeria (324); Netherlands (308); } \\
\text { Russian Federation (269); Turkey (247); Republic of Korea (241); Kenya (215); }\end{array}$ \\
\hline $21-30$ & $\begin{array}{l}\text { Hong Kong (213); Iceland (211); Israel (210); Mexico (209); Spain (206); Viet Nam (199); Brazil (198); } \\
\text { Sweden (197); Ireland (197); Italy (187); }\end{array}$ \\
\hline $31-40$ & $\begin{array}{l}\text { Thailand (180); Finland (165); Islamic Republic of Iran (154); Saudi Arabia (147); Jamaica (144); } \\
\text { Romania (142); Egypt (138); Ghana (130); Greece (130); Poland (125); }\end{array}$ \\
\hline $41-50$ & $\begin{array}{l}\text { Japan (124); Mauritius (117); United Arab Emirates (115); Bangladesh (110); Zambia (103); Portugal } \\
\text { (100); New Zealand (94); Belgium (93); Zimbabwe (93); Taiwan (90); }\end{array}$ \\
\hline $51-60$ & $\begin{array}{l}\text { Norway (89); Switzerland (88); Ukraine (81); Chile (80); Trinidad and Tobago (77); Austria (75); } \\
\text { Ethiopia (74); Uganda (74); Colombia (72); United Republic of Tanzania (66); }\end{array}$ \\
\hline $61-70$ & $\begin{array}{l}\text { Sri Lanka (55); Peru (52); Hungary (52); Lebanon (51); Nepal (51); Fiji (50); Denmark (43); Lithuania } \\
\text { (38); Croatia (38); Namibia (36); }\end{array}$ \\
\hline $71-80$ & $\begin{array}{l}\text { Argentina (35); Algeria (35); Malawi (35); Cameroon (35); Puerto Rico (33); Maldives (31); Malta (30); } \\
\text { Slovakia (29); Czech Republic (27); Oman (27); }\end{array}$ \\
\hline $81-91$ & $\begin{array}{l}\text { Qatar (26); Botswana (26); Ecuador (23); Albania (22); Jordan (22); Kuwait (22); Estonia (21); Serbia } \\
\text { (21); Bolivarian Republic of Venezuela (21); Guyana (20); Slovenia (20); }\end{array}$ \\
\hline $92-101$ & $\begin{array}{l}\text { Cyprus (18); Morocco (18); Luxembourg (17); Bulgaria (16); Occupied Palestinian Territory (16); } \\
\text { Somalia (16); Bahamas (16); Iraq (16); Tunisia (15); Kazakhstan (15); }\end{array}$ \\
\hline $102-113$ & Curacao (14); Swaziland (14); Syrian Arab Republic (12); Virgin Islands (US) (12); Yemen (12) Barbados \\
\hline
\end{tabular}

${ }^{5}$ Bolded countries are members of the OECD. 


\begin{tabular}{|l|l|}
\hline & $\begin{array}{l}\text { (12); Costa Rica (12); Guatemala (11); Papua New Guinea (11); Uruguay (11); Bahrain (11); Bosnia \& } \\
\text { Herzegovina (11); }\end{array}$ \\
\hline $114-124$ & $\begin{array}{l}\text { Honduras (10); Macao (10); Uzbekistan (10); Kyrgyzstan (10); Bhutan (9); Guam (9); Latvia (9); Latvia } \\
\text { (9); Moldova (9); Myanmar (9); Saint Vincent and the Grenadines (9); Georgia (9); }\end{array}$ \\
\hline $125-137$ & $\begin{array}{l}\text { Cote d'Ivoire (8); Vanuatu (8); Rwanda (8); Antigua and Barbuda (7); Saint Lucia (7); Senegal (7); } \\
\text { Cambodia (6); Panama (6); Paraguay (6); Brunei Darussalam (5); Dominican Republic (5); Lesotho (5); } \\
\text { El Salvador (5); }\end{array}$ \\
\hline $138-143$ & $\begin{array}{l}\text { Bermuda (4); Cayman Islands (4); Mozambique (4) Sudan (4); Suriname (4); The Former Yugoslav } \\
\text { Republic of Macedonia (4); }\end{array}$ \\
\hline $144-155$ & $\begin{array}{l}\text { Montenegro (3); Armenia (3); Plurinational State of Bolivia (3); Afghanistan (3); Djibouti (3); Lao } \\
\text { People's Democratic Republic (3); Angola (3); Nicaragua (3); Solomon Islands (3); Seychelles (3); } \\
\text { South Sudan (3); Cuba (3); }\end{array}$ \\
\hline $156-163$ & $\begin{array}{l}\text { Azerbaijan (2); Belarus (2); Belize (2); Democratic Republic of Congo (2); Gambia (2); Haiti (2); Libya } \\
\text { (2); Togo (2); }\end{array}$ \\
\hline $164-178$ & $\begin{array}{l}\text { Guinea (1); Burundi (1); Republic of Congo (1); Dominica (1); Federated States of Micronesia (1); } \\
\text { Faroe Islands (1); Guernsey (1); Benin (1); Jersey (1); Kiribati (1); Saint Kitts and Nevis (1); Madagascar } \\
\text { (1); Mongolia (1); Turkmenistan (1); Virgin Islands (Br) (1); }\end{array}$ \\
\hline Totals: 178 countries; 42,0854 downloads
\end{tabular}

